\section{Roland Barthes: semiologia, mídia e fait divers}

\section{RESUMO}

A Semiologia, segundo Roland Barthes, é povoada por traços particulares. Não se empareda no escaninho lingüístico. Reivindica outros contornos. Persegue o translingüístico. Nessa paisagem, o papel da Mídia doa-se como objeto de suas pesquisas semiológicas. No diagrama de suas limitações, o presente ensaio se agenciará nas relações entre a Semiologia barthesiana e a Mídia. Refletirá sobre algumas categorias básicas, que as simbiotizam.

\section{ABSTRACT}

Roland Barthes's semiology is gifted with especial traits. It cannot be cemented within the walls of linguistics. It calls for other reference points. It goes after a translinguistics. It invests on the role of the Media as the object of its researches. This essay, despite its limitations, will attempt to establish the relationship between Barthes's semiology and the media, reflecting on some basic categories which symbolize them.

\section{PALAVRAS-CHAVE / KEY-WORDS}

- Discurso (Discourse)

- Semiologia (Semiology)

- Roland Barthes
Roberto Ramos

Prof. Dr. FAMECOS/PUCRS
BARTHES CONSEguIU MONTAR a sua Semiologia, com fisionomia própria. Os traços iniciais foram construídos no compasso do Estruturalismo funcionalista, modelado por Saussure. Depois, dimensionou a configuração de sua singularidade metodológica. Perfilou o seu horizonte estrutural, com um grifo dialético. Abriu a vitrine para a densidade semiológica da Mídia.

O papel da Mídia encontrou um diagrama de análise na formulação da categoria Fait Divers. Tal relação será o objeto do presente ensaio, que, assujeitado às suas limitações, procurará estabelecer alguns questionamentos sobre as pertinências e sobre as impertinências, aí, inscritas.

\section{Semiologia e mídia}

O repertório teórico de Barthes se orquestrou no encantamento do Estruturalismo, de Saussure. Ele organizou com partituras, provenientes do Positivismo, os tons funcionalistas, para o estudo do universo dos signos. Sublinhou a indissociabilidade entre a Fala e a Língua, priorizando esta como objeto de investigação.

Tal arranjo trouxe uma repercussão luminar. A Língua foi descartada de suas raízes sociais. Passou a ter vida própria. Fetichizou-se em uma autonomia, órfã de sociedade, nascida e com sobrevivência, patrocinada por uma geração espontânea, como uma musicalidade metafísica.

Barthes cultivou o fascínio da perspectiva saussuriana. Seguiu-a dentro da régua e do compasso, delimitando a sua dimensão do estudo dos signos. Mesmo assim, notabilizou a particularidade de suas pesquisas, através da singularidade de um 
objeto específico: o papel mítico da Mídia.

$\mathrm{Na}$ década de 50 , quando a Mídia não era, ainda, um polvo, com tentáculos globalizantes. Estava circunscrita à peregrinação das Agências Internacionais, que rasgavam céus e mares, com o pecado original da defasagem temporal. Barthes decodificou a sua importância antes que ela se revelasse importante.

A obra Mitologias, em sua angulação saussuriana, já perpetua alguns indícios. Rascunha o quotidiano da vida francesa, permeado pela influência midiática, como significante da produção mítica. A contemplação de tal objeto será o pré-requisito que levará o semiólogo a se desencantar com o encanto do Estruturalismo, com o seu desenho funcionalista.

Passadas duas décadas, Barthes se desamarra das amarras do antigo espelho-mestre. A Aula é uma obra, que forja a tessitura de uma Semiologia, com os acordes, marcadamente, barthesianos. As notas do Estruturalismo se modificam. A planície funcionalista perde o lugar. Chega a vez da cordilheira dialética.

O signo não é mais vislumbrado, como um significante de uma verdade absoluta, fixa, com colorações ahistóricas. É visto no preto-e-branco da superfície da historicidade, um terreno de areia movediça, para aqueles que se aconchegaram no perímetro da logicidade do cadáver da anatomia da exatidão.

A ruptura não foi uma simples troca de vestuário, em que Barthes desembarcou do terno funcionalista, para se abotoar no traje esportivo da abordagem dialética. Significou a mudança de significante, importando um outro viés metodológico. O lingüístico se despiu de sua aura monopolizante. Foi desfeito o seu halo sincrético de ponto de partida e de ponto de chegada.

Barthes redimensionou o volume e o peso do lingüístico. Fez-lhe encolher ao calibre de ponto de chegada. O translingüístico, como anotação interdisciplinar, foi convertido em ponto de chegada. Abriu- se à pronúncia da dialogicidade com outras disciplinas, sem misturar alhos com bugalhos. Alinhou a relação dos eventos sociológicos e psicológicos, com o fio-de-prumo dos limites, preservando a especificidade de seus respectivos objetos.

Tal metamorfose de abordagem epistemológica pode abrigar diferentes variáveis, como fermento de motivação. Uma das quais se anota na obra Mitologias, que, na sua incipiência, já contemplava um indício da Semiologia barthesiana. Grifava a particularidade de suas pesquisas semiológicas, debruçadas, sobremodo, na importância da Mídia, quando não se desconfiava de seu papel hegemônico no design civilizatório, esboçado, sobretudo, nas últimas duas décadas do século XX.

Barthes, em seus caminhos e descaminhos epistemológicos, disponibilizou a sua sabedoria em doar um novo objeto de estudo para a tessitura da Semiologia: o socioleto da Mídia. A criatura, ao ser feita, desfez o seu criador. Desconstruiu o seu alicerce de um Estruturalismo, montado nos andaimes do Funcionalismo, construindo uma abordagem dialética.

Pode-se tangenciar a trajetória teórica barthesiana, em seu repertório de nuances, com diferentes possibilidades de hipóteses. Uma delas relaciona o perfil singular de sua Semiologia, com um horizonte lingüístico e translingüístico, à eleição da Mídia, como objeto invariante, direta ou indiretamente, posto na prateleira de suas pesquisas.

\section{Mídia e cultura}

Uma categoria básica no halo teórico barthesiano é a Cultura. Ela se sincretiza na maresia do quotidiano, como "as nossas conversas, as nossas leituras". Decodificase como intertexto, materializando os nós, que unem o evento da linguagem ao evento social.

Na Cultura desta categorização, 
ou seja, no seu intertexto há rastros de influência, sobretudo, de dois teóricos. Abriga a noção de Dialogicidade, estabelecida por Mikhail Bakhtin, e a de Intertextualidade, montada por Julia Kristeva, que, inclusive, foi aluna de Barthes. Observa-se a anotação, que tece um cordão umbilical entre a anatomia da Língua e a anatomia da Fala.

Barthes (s.d.) procura desnovelar as amarrações de classe, circunscritas e inscritas no universo da Mídia:

"O proletariado (os produtores) não tem nenhuma cultura própria; nos países ditos desenvolvidos, a sua linguagem é pequeno-burguesa, porque é a linguagem, que lhe é oferecida pelas comunicações de massa (imprensa, rádio e televisão): a cultura de massa é pequenoburguesa"(...)

Ele (s.d.) enseja outro acréscimo:

'(...) A idéia de degradação pode parecer moral, vinda de um burguês, com saudades da cultura passada: dou-lhe, muito pelo contrário, um conteúdo objetivo, estrutural: há degradação, porque não há invenção: os modelos são repetidos, aplanados, pois a cultura pequeno-burguesa (censurada pelo Estado) exclui a própria contestação que o intelectual pode trazer à cultura burguesa: é a imobilidade, a submissão aos estereótipos (a conversão das mensagens em estereótipos), que define a degradação. Pode dizer-se que a cultura pequeno-burguesa, na cultura de massas, é a cultura burguesa que regressa à cena da História, mas como uma farsa (é conhecida esta imagem de Marx"'”(...)

Há, na Cultura do semiólogo, vestígios, bem conservados, provavelmente, oriundos de algumas leituras da Escola de Frankfurt. O papel ideológico da Mídia é radiografado por um ponto de vista crítico, nutrido por uma visão interdisciplinar, sem créditos, invariante na alquimia de formulações barthesianas.

A categoria Padronização, de Theodor Adorno e Max Horkheimer (1987), é o fio de prumo, que dimensiona o perímetro das concepções críticas de Barthes sobre o papel cultural dos arames farpados da Mídia. Ele a conecta com a sua categorização de Estereótipo, fortalecendo a urdidura do lingüístico e do translingüístico.

No engenho de Barthes (s.d.), - Estereótipo se categoriza, com luminosidade. Significa o sentido inato. Não passa de uma prótese de linguagem. É uma cristalização, como tal ganha contornos de absoluto. Veste-se de verdade intocável e irretocável. Não possui convivência com a contradição, porquanto é a própria solidez da imposição.

$\mathrm{Na}$ prospecção de uma ficcional árvore genealógica do Estereótipo, podem ser encontradas as raízes no Senso Comum. Este aparece translúcido, envolto na maximização das águas do empirismo, que lhe mata a sede e lhe embriaga, como aguardente, que borra a visibilidade do real.

Se o Senso Comum fez cátedra de superficialidade na fabulação de Axiomas, mandamentos concisos de uma experiência elástica, válida para todo o sempre, não descuidou do cultivo das safras dos Estereótipos. Ambos são frutos gêmeos do mesmo pé, que se mantém de pé na ilusão de que o empírico é a raiz essencial da vegetação da verdade.

No Socioleto da Mídia, em seu saguão de tecnologia, o Senso Comum é uma onipresença.

Encontra-se travestido com os panos de algum pendor científico, com o pano do Positivismo, ora combinado com as lãs da Dialética hegeliana. A noção do absoluto abençoa tal design, por intermédio do amém do Estereótipo.

O continente do Estereótipo, em 
sua incontinência, é um "dedo-duro". Circunscreve a sua jurisprudência a uma maiúscula funcionalidade. Cabe-lhe apenas a tarefa de apontar. Não precisa fazer mais do que isso. $O$ seu reinado se move pela concisa e pródiga conjugação do verbo "mostrar". É operfeito epitáfio da demonstração.

Em seu sentido metonímico, o Estereótipo não está só. Não se encontra ilhado. Encontra o seu hábitat perfeito, sob medida na discursividade midiática, que lhe enseja a convivência com os seus notáveis alter egos: as bem-afamadas e bem vendidas faces, respectivas, da informação e da democracia.

Nesse relevo de dominação, Barthes projeta a sua crítica. Ele pinta a importância cultural da Mídia, traçando a sua aquarela pequeno-burguesa, esta forma de fala que naturaliza e eterniza a sociedade burguesa, sem mentir, pois jura dizer a suprema verdade. Não nega nada. Apenas torna tudo inocente. Denega, assim, os seus compromissos de classe. Eis a moldura de seu Mito.

\section{Mídia e discurso}

De início, Barthes (1994) faz um resgate etimológico do termo Discurso. Ele anota, com um dever quase matemático, que "discursus é, originalmente, a ação de correr para todo o lado, são idas e vindas, 'demarches', intrigas”. É uma teia lúdica, que brinca, com saber e sabor, com a mobilidade dos signos.

À questão etimológica, existe a agregação de uma especificidade. O semiólogo (s.d.: 121) parte para uma pormenorização. Estabelece que a "descrição formal dos conjuntos de palavras, superiores à frase (a que chamaremos, por comodidade, discurso), não data de hoje: de Górgias ao século XIX, foi o objeto próprio da antiga Retórica".

Observa-se, nas duas citações anteriores, o rigor metodológico de Barthes. Ele, ao resgatar a etimologia e ao categorizar o Discurso, em um panorama temporal, cumpre o ritual da atividade estruturalista. Preserva a prioridade e a prevalência do Significante pelo seu sentido de origem e de nome.

O semiólogo (s.d.) propõe duas formas básicas de Discurso, através de suas relações com o Poder:

"(...)Nas sociedades atuais, a mais simples divisão das linguagens incide sobre a relação com o Poder. Há linguagens, que se enunciam, se desenvolvem, se marcam na luz (ou na sombra) do Poder, dos seus múltiplos aparelhos estatais, institucionais, ideológicos; chamarIhes-ei de linguagens ou discursos Encráticos. E, de outro lado, há linguagens que se elaboram, se procuram, se armam fora do Poder e/ou contra ele; chamar-Ihes-ei linguagens ou discursos Acrá-ticos."

Barthes (s.d.: 121) estabelece acréscimos:

"Estas duas grandes formas de discurso não têm o mesmo caráter. $\mathrm{A}$ linguagem Encrática é vaga, difusa, aparentemente, 'natural' e, portanto, pouco identificável: é a linguagem da cultura de massa (imprensa, rádio e televisão) e é, também, num sentido, a linguagem da conversação, da opinião corrente (da doxa); toda esta linguagem Encrática e, ao mesmo tempo, clandestina (não podemos reconhecê-la facilmente) e triunfante (não podemos escapar-lhe): direi que ela é pegajosa. A linguagem Acrática, essa é separada, cortante, desligada da doxa (é, portanto, paradoxal); a sua força de ruptura vem-lhe de ser sistemática, construída sobre um pensamento, não sobre uma ideologia. Os exemplos são mais imediatos 
desta linguagem Acrática. Seriam, hoje em dia, o discurso marxista, o discurso psicanalítico e, permitam-me que acrescente, em menor grau, mas, estatutariamente notável, o discurso estruturalista".

Há uma pluralidade, própria do Discurso Acrático, como sublinha o semiólogo (s.d.: 121):

"Mas o mais interessante, talvez
seja que, mesmo na esfera acrática,
produzem-se, de novo, divisões,
regionalidades e antagonismo
de linguagem: o discurso crítico
fraciona-se em falares, em cercados,
em sistemas. Tenderia, de bom
grado, a chamar a estes sistemas
discursivos Ficções (é uma palavra
de Nietzsche) e a ver nos intelectuais,
naqueles que formam, ainda segundo
Nietzsche, a classe sacerdotal, a
casta, encarregada de elaborar,
como artistas, essas Ficções de
linguagem(...)."

Ao eleger a Mídia como objeto de suas incursões semiológicas, Barthes trazIhe uma reivindicação, com sabor de prérequisito. É a necessidade de compartilhar com a dimensão interdisciplinar, um tanto desarrumada, sem critérios luminosos de diálogos entre os significantes das disciplinas, mas com uma invariância: a abordagem dialética.

A Dialética marxista vai endossar os passos, que transcenderam ao perímetro do lingüístico, para abraçar o planalto do translingüístico. Eis o pedágio, pago pelo semiólogo, ao anotar a essencialidade do papel midiático na discursividade da segunda metade do século XX.

A formulação dos discursos Encrático e Acrático ostenta uma amarração. Há uma conexão respectiva com a doxa, em seu sentido imaginário, e com o paradoxo, como viés de um horizonte, revestido pelos panos da cientificidade. A pluralidade, em sua moeda, de faces contraditórias, é o cifrão de um grifo dialético, que abraçará, invariantemente, o Estruturalismo, o Materialismo Histórico e a Psicanálise nos rascunhos e nos textos finais de Barthes.

A discursividade está comprometida com o Poder. O semiólogo (s.d.: 10-12) o perfila, como a "libido dominandi". Está relacionado com a história inteira do homem, e não somente com a história política. É um "parasita do organismo transocial", que se pronuncia no escaninho da Linguagem, na especificidade da prateleira da Língua.

A concepção barthesiana propõe um elo interdisciplinar com a Psicanálise, criada por Freud (1987) em 1895. Sintoniza o Poder com a categoria Libido, em seu desenho biológico, que tece o enredo do Inconsciente na paisagem da primeira infância. É a forma de sublinhar a sua invariância sob o ponto de vista subjetivo e social.

A Libido tem recebido um oceano de leituras e uma maresia de interpretações. Algumas a simplificam, tornando-a um mero e reducionista sinônimo de prazer sexual. Outras conseguem descortiná-la, com mais horizonte, como energia prazerosa em suas multifacetadas versões.

O Poder, como Libido Dominante, é a energia prazerosa, própria do Instinto de Eros, que concede sentido ao viver humano. Apresenta várias manifestações, uma das quais é a sexualidade. O seu perfil biológico, de face inata, fixa toda a condição de supratemporalidade e de supra-espacialidade. São os seus tons invariantes.

Ainda que invariante, a Libido se particulariza em diferentes fases. Passa pela oral, anal e fálica, constituintes da primeira infância. $\mathrm{O}$ mesmo ocorre com o Poder, com sua pose invariante no curso histórico, que se singulariza no cipoal de cada conjuntura histórica.

Barthes recicla a noção weberiana de Poder, como dominação. O homem é indissociável da energia prazerosa, que 
Ihe impõe, dialeticamente, a simbiose liberdade-submissão. É a concepção althusseriana (1985) de sujeito, habitando - condomínio da intertextualidade barthesiana.

Além de sua face biológica, o Poder apresenta uma outra face: cultural. Habita a Linguagem, nos escaninhos da Língua, como instituição social, que se reproduz transocialmente. É uma invariante na História, porquanto possui, nesse sentido, supra-espacialidade e supratemporalidade, inscritas nas variações conjunturais.

Nesse horizonte de Barthes (1993), O Mito é uma forma de fala, estabelecida pelos alicerces da conotação. Não nega a factualidade histórica, apenas a torna ingênua. $A$ sua função é a naturalização e a eternização da sociedade burguesa. Eis o seu calibre ideológico.

$\mathrm{Na}$ aparência, a questão da "sociedade burguesa" pode patrocinar um engano. Parece tornar o Mito como um produto, indissociável, de sua condição burguesa, porém não é isso. Antes, revela uma preocupação com a cientificidade. É uma delimitação do objeto de estudo, no caso a Mídia francesa, autorizada pelo Princípio de Pertinência.

A obra, Mitologias, é angulada pela crítica ideológica. O seu intertexto abriga as presenças de Hjelmslev, pela conotação, de Durkheim, pelo Mito, estratificado como representação coletiva, e de Marx, pela Ideologia em seu sentido napoleônico, como distorção.

Tal ecumenismo teórico não é uma fisionomia do despropósito, como possa conceber o embriagado pela aguardente das aparências. A reunião de Hjelmslev, Durkheim e de Marx está alinhada pelos laços da interdisciplinaridade, ainda que careçam da luminosidade da explicitude.

No curso das páginas de Mitologias, há a construção de uma ambivalência. As categorias de Mito e de Ideologia estão sobrepostas. Ambas são gêmeas univitelinas. Respiram pelo pulmão único da conotação. Encenam a legitimação da sociedade burguesa.

A própria configuração do Mito é indissociável da questão ideológica. Estão colados pelos vértices lingüísticos e translingüísticos, fixados na deformação de sentido. Transpiram o conceito particular de Ideologia, buscado por Marx em Napoleão Bonaparte.

As reflexões teóricas do semiólogo sobre a concepção de Discurso e suas respectivas tipologias, bem como as questões vinculadas ao Poder, Mito e Imaginário, são decisivas. Referendam que o objeto-matriz de suas incursões semiológicas é a Mídia, em sua densidade escrita.

\section{$4 \quad$ Mídia e fait divers}

A expressão francesa Fait Divers designa, em sua generalidade, a informação sensacionalista. A sua pronúncia é bem anterior ao advento da Imprensa. Já existia em diferentes produções culturais na Idade Média, habitando a aura dos cantos dos menestréis.

Angrimani (1994:27) observa que, em 1631, A Gazette de France lançou "edições extraordinárias, de grandes tiragens, consagradas aos Fait Divers sensacionais. Depois, os editores de outros jornais passaram a publicá-los, com mais intensidade, para aumentar os seus rendimentos.

$\mathrm{Na}$ Literatura, o Fait Divers desempenhou um papel importante. Inspirou inúmeros romancistas, entre os quais, cabe sublinhar Balzac, Flaubert e Stendhal. Também Sartre e Beauvoir o cultivaram na ribanceira de seu perímetro existencialista. O mesmo ocorreu com Breton, semeando-o em sua estrutura poética, como grifa Walker (1995).

Em um mosaico genérico, podese afirmar que o Fait Divers é a informação sensacionalista. Mimetiza conflitos, cravados na Causalidade e na Coincidência, de acordo com Barthes 
(1971). Interpela o receptor pelos tentáculos da emoção, independente de seu estilo jornalístico.

Barthes (1971) arrumou-lhe uma tipologia básica, ancorada em duas categorizações básicas: Causalidade e Coincidência. Ambas se subdividem em subtipos, direcionados à compreensão da excepcionalidade, introdutora da noção de conflito, em sua performance sensacional.

O primeiro tipo, o Fait Divers de Causalidade, apresenta duas manifestações:

a) Causa Perturbada: há o desconhecimento causal e quando uma pequena causa produz um grande efeito;

b) Causa Esperada: quando a causa é normal, a ênfase recai nos personagens dramáticos - mãe, criança e velho (Barthes, 1971: 271-276).

$\mathrm{Na}$ Causa Perturbada, a excepcionalidade está localizada no porquê da factualidade. Existe um efeito, porém a causa é desconhecida ou deformada pela imprecisão, ou pela ilogicidade. Em quaisquer das possibilidades, há a formalização de uma situação de conflito.

O conflito vem à tona pela factualidade. Materializa-se, narcisicamente, no presente, mas conserva o motivo reprimido, submerso no porão do passado. $O$ determinado é visto, solidificado pela transparência do fato, embebido pela historicidade; o determinante, oculto, abstrato, deixando apenas os indícios de seus domínios.

Verifica-se que há, formalmente, a estruturação de uma situação conflitiva. Esta interpela e obtém reconhecimento não apenas pelo dito, mas, sobretudo, pela forma de dizer. Ocorre a mimetização da dialética da subjetividade. A consciência é o dito, o efeito, o factual, o denotado, o determinado; a Inconsciência, o nãodito, a causa, o contexto, o conotado, o determinante.

A condição de sujeito é uma condição conflitiva. O interpelado se reconhece na factualidade, trazida pelo Fait Divers - Ele, também, é um efeito, em nível de consciência, com causas desconhecidas, imprecisas e ilógicas, guardadas a sete chaves no porão do Inconsciente. Ao se reconhecer, vive o que está fora, como se fosse seu. É a Identificação Projetiva, que enseja a Catarse.

$\mathrm{Na}$ Causa Esperada, a excepcionalidade troca de lugar. Desloca-se para os protagonistas, que são os agentes do conflito, seja no pêlo de vítima ou de réu. A dramaticidade apanha três tipos de sujeitos básicos: mãe, criança e velho. Eles mimetizam os diversos ciclos da existência humana. Simbolizam a fragilidade e a pureza humanas.

Observa-se que, no Fait Divers de Causalidade, através da Causa Perturbada e da Causa Esperada, existe a estruturação de um conflito não-classificado pelo conhecimento humano. Torna-se inexplicável aos recursos da racionalidade e dos pressupostos do intelectual. O seu código fala a língua da emocionalidade. Exila-se da dimensão histórica.

Os sujeitos relativos não conseguem ter respostas para a situação conflitiva estabelecida na superfície sintagmática do fato. Ficam impotentes, sem recursos lógicos de compreensão. Recorrem a um Sujeito Absoluto, tal qual acontecia na Tragédia grega, quando um 'Deus-exMachina" entrava em cena, para contornar os impasses incontornáveis historicamente. Prevalece a lógica da Fatalidade.

A Fatalidade é o Sujeito Absoluto, - grande pai transcendental, que possui a explicação para o inexplicável. É a iluminação do oculto, o conhecimento do desconhecido pela sua divinal presença onipresente e onisciente. Assume a responsabilidade sobre todas as coisas. É o fiador perfeito para todas as imperfeições e desvios, inscritos na relatividade histórica da sujeição.

No Fait Divers de Causalidade, pelas singularidades da Causa Perturbada e 
da Causa Esperada, há a estruturação de conflitos, que interpelam. São reconhecidos, porque reproduzem a dialética da subjetividade. Proporcionam a Identificação Projetiva, que estabelece um final feliz, uma saída catártica: a Fatalidade, o Sujeito Absoluto, garantia de harmonização e suprema desculpa para todas as culpas, desde que, com liberdade, seja pago o dízimo da submissão.

O segundo tipo, proposto por Barthes (1971: 271-274), é o Fait Divers de Coincidência, subdividido em duas manifestações:

a) Repetição: é o igual, que se reproduz, com diferença, conforme Lacan (1990);

b) Antítese: duas perspectivas diferentes, antagônicas, são fundidas em uma única realidade. Uma de suas formas de expressão é o Cúmulo (a situação de má sorte), figura da Tragédia grega.

Coincidência despe o homem de sua responsabilidade histórica. Conforta-Ihe com a irresponsabilidade, desculpando as suas próprias culpas. Permite-lhe regredir a um estágio de menor idade, que Ihe assegura a impunidade em relação a seus atos. É a garantia de transferir a responsabilidade para a noção de Fatalidade.

A Repetição de uma factualidade, sem uma lógica histórica, remete para a noção de Coincidência. $O$ repetir não é a reprodução do original, como cópia, mas a sua reprodução, com diferenças. Instaura a onipresença da factualidade, que se mantém além da circunstancialidade.

O Inconsciente se reconhece, através da Identificação Projetiva, não necessariamente pela reprodução do evento recalcado, mas, sobretudo, por uma analogia formal do enfoque conflitivo. Torna-se imutável, por intermédio da Repetição, que o conserva para além de sua gênese.

A Antítese mistura os opostos em uma mesma dimensão do real. Os dissociáveis se tornam indissociáveis, como se fossem gêmeos univitelinos. Os desiguais ficam igualados por uma inteligência absoluta, sem significação corpórea, que reina na abstração. Uma de suas manifestações é o Cúmulo, onde o trágico faz as suas vítimas. Verifica-se que a Repetição e a Antítese estabelecem a Coincidência, reproduzindo a linguagem trágica, com a presença do "Deus-ex-Machina", tal qual o Fait Divers de Causalidade. Mesmo com outras particularidades, com um outro atalho, o caminho é o mesmo: a Fatalidade, como Sujeito Absoluto, para desatar os nós coincidentes.

$\mathrm{Na}$ teorização de Barthes (1971: 299), o conceito de Estrutura é fundamental, Ele o explica da seguinte forma:

A estrutura é, pois, na verdade, um simulacro do objeto, mas um simulacro dirigido, interessado, uma vez que o objeto imitado faz algo que permanecia invisível, ou se preferirmos, ininteligível no objeto natural.

Barthes realiza um simulacro, dirigido, do Fait Divers. Dá-lhe um conceito. Oferece-lhe estrutura com duas categorias: Causalidade e Coincidência. Ambas estão voltadas para a classificação da excepcionalidade, fixada na dimensão do conflito, respectivamente, através da Causa Perturbada, Causa Esperada, Repetição e Antítese. Há a revelação da Fatalidade, como Sujeito Absoluto, análogo ao 'Deusex-Machina" da linguagem trágica.

$\mathrm{Na}$ abordagem estruturalista, o essencial não é o dito. As histórias, os protagonistas e as circunstâncias variam no tempo e no espaço. O que importa é a estrutura, a forma de dizer, o significante supratemporal e supra-espacial, que possui invariância perante quaisquer possibilidades de mutação.

O semiólogo (1971) assinala que o Fait Divers tem um consumo imediato. Notabiliza-se pela sua imanência. É fechado no seu próprio contexto, a única dimensão do seu saber. Não reivindica 
nada que possa transcender o seu próprio território imagético. Está preso ao presente, cristalizado no aqui e no agora. É narcísico por excelência.

O Fait Divers é, por natureza, sensacionalista. Tanto pela Causalidade, tanto pela Coincidência interpela a emoção do receptor. A sua estrutura é marcada e demarcada pela noção de conflito, que oportuniza a Identificação Projetiva e, em conseqüência, a Catarse.

Em suas diferentes manifestações, é uma onipresença na vitrine da Mídia, seja impressa ou eletrônica, com plurais abordagens. Aparece no tratamento da realidade e da ficção, seja nos telejornais, nas telenovelas, nos talk shows, nos programas de humor, nos noticiários da Imprensa e do Rádio e, ainda, na Publicidade e na Literatura.

Os dominantes e os dominados, ricos e pobres, belos e feios compõem um rebanho harmônico e democrático apesar de suas singularidades. Possuem o mesmo ancoradouro. Compartilham, pelos atalhos da Causalidade e da Coincidência, do mesmo caminho: o porto seguro da Fatalidade, o Sujeito Absoluto, suprema e divina explicação para o que existe entre o céu e a terra.

Portanto, foi possível verificar a importância do papel da Mídia, como objeto das pesquisas semiológicas de Barthes. Ele formulou categorias, como Discurso, Cultura, Estereótipo, Poder, Mito, Imaginário e Fait Divers, que respondem e correspondem às reivindicações de investigação do Socioleto midiático. Contemplou o seu olhar, com a perspectiva translingüística, nutrida de uma abordagem dialética .

Referências

ADORNO, Theodor e HORKHEIMER, Max. Dialética do
Esclarecimento - Fragmentos Filosóficos. $2^{\mathrm{a}}$ ed. Rio de Janeiro: Zahar, 1987.

ANGRIMANI, David. Espreme que sai Sangue. São Paulo: Summus, 1994.

BARTHES, Roland. Mitologias. 9.a ed. Rio de Janeiro: Bertrand Brasil, 1993.

. Aula. São Paulo: Cultrix, s. d.

. Escritores, Intelectuais, Professores e outros Ensaios.

Lisboa: Presença, s.d.

O Rumor da Língua. Lisboa: Edições 70, s. d.

Fragmentos de um Discurso Amoroso. 13a. ed. Rio de Janeiro: Francisco Alves, 1984.

. Ensaios Críticos. Lisboa: Edições 70, 1971.

FREUD, Sigmund. A Interpretação dos Sonhos. RJ: Imago, 1987.

LACAN, Jacques apud HARARI, Roberto. Uma Introdução aos Quatro Conceitos Fundamentais de Lacan. Campinas: Papirus, 1990. 1994.

Seminário: As Psicoses. Rio de Janeiro: Jorge Zahar,

WALKER, David. Outrage and Insight: Modern French Writters and the Fait Divers. Oxford/Washington: Berg Publishers, 1995. 